\title{
Review
}

\section{Olga Tokarczuk: The Right Time and Place}

Olga Tokarczuk. Bieguni. Kraków, Poland: Wydawnictwo Literackie, 2008.

- Flights. Translation of Bieguni from Polish into English by Jennifer Croft. New York:

Riverhead Books, 2018.

—. Księgi Jakubowe. Kraków, Poland: Wydawnictwo Literackie, 2014.

_Les Livres de Jakób. Translation of Księgi Jakubowe from Polish into French by Maryla Laurent. Paris: Les Éditions Noir sur Blanc, 2018.

On October 10, 2019 the Swedish Academy awarded the Polish writer Olga Tokarczuk the 2018 Nobel Prize for Literature "for a narrative imagination that with encyclopedic passion represents the crossing of boundaries as a form of life." The winner of two prestigious Nike Awards (the Polish equivalent of the French Prix Goncourt), plus multiple awards in Poland, Germany, and Sweden for her fiction and essays, Tokarczuk was also the 2018 recipient, along with her English translator Jennifer Croft, of the Man Booker International Prize for her novel Flights. Tokarczuk, however, remains little known in the anglophone world; at the time of the Nobel announcement, for example, only four of her books had appeared in English translation. ${ }^{2}$ This essay will examine Tokarczuk's works, especially Flights and Księgi Jakubowe (the Englishlanguage version, The Books of Jacob, is scheduled for publication in March 2021), with special attention to Tokarczuk's recurrent themes and the challenges of rendering her often allusive and myth-laden prose into English.

Born in 1962 in Sulechów, a small town in western Poland in the area known as Silesia, Tokarczuk now lives in a small village, Krajanów, in rural Lower Silesia, near the Czech border. Silesia itself had at times been part of Germany,

1 Press release, Swedish Academy, 10 October 2019.

2 In addition to Flights, these translations, all by Antonia Lloyd-Jones, are House of Day, House of Night, 2002 (Dom dzienny, dom nocny, 1998); Primeval and Other Times, 2010 (Prawiek $i$ inne czasy, 1996); and Drive Your Plow Over the Bones of the Dead, 2019 (Prowadź swój plug przez kości umartych, 2009). Drive Your Plow Over the Bones of the Dead served as the basis of a Polish movie, Pokot (English translation, Spoor), directed by the renowned Agnieszka Holland. Translations of many of Tokarczuk's works exist in German, French, Russian, and numerous other languages.

Delos Vol. 35, No. 1, pp. 101-115. Copyright (C) 2020 University of Florida Press. doi: $10.5744 /$ delos.2020.1009 
with the border often shifting between the two countries. Some members of her father's family had originally come from Ukraine. While studying psychology at the University of Warsaw, Tokarczuk was greatly influenced by the writings of Carl Gustav Jung. After working for a time as a psychologist, she left this profession for full-time writing, having decided that she was more disturbed than some of her patients. Although a best-selling author in Poland, Tokarczuk is disliked by some of the more conservative elements in the country for her calling attention to historical acts of injustice by Polish authorities and for her activism on behalf of the environment.

The unique properties of Polish grammar are highly relevant to Tokarczuk's work. "In the language in which I write," according to Tokarczuk, "the future and the past differ only by one vowel. E transforms into $\mathrm{Y}$ and this sounds like a calling." The words "future" (przyszłość) and "past" (przeszłość) are almost identical in Polish, but not in other modern European languages or even Russian. Not only is Tokarczuk signaling that her works will weave between several centuries ("future" and "past"), but she is also indicating that she has a "calling" to capitalize fully on the linguistic features of Polish. Examination of the Polish text, therefore, may sometimes contribute significantly to our understanding of her work.

\section{Flights (Bieguni)}

Flights, Jennifer Croft's version of the Polish Bieguni, is a masterpiece of translation. Her language is lively, by turns colloquial and academic, capturing various voices and registers, including that of a homeless woman, novice and seasoned writers, professors, and early modern scientists and intellectuals. Flights consists of 116 unnumbered chapters or vignettes, often interconnected, ranging from a single paragraph of only three sentences to a narrative of thirty-five pages. The chapters interweave multiple strands across several centuries and various locations in Poland, Croatia, Greece, New York, and other places. There is a narrator, identified by the pronoun I: the first chapter

3 Anna In w grobowcach świata [Anna In and the Tombs of the World] (Kraków: Znak, 2006): "W języko, w którym piszę, przeszłość i przyszłość róznią się tylko jedną samagłoską. E przechodzi w Y i brzmi to jak zawołanie." English translation by Bożena Karwowska in "Mythical Subversions (Olga Tokarczuk)," in Tamara Trojanowska et al., editors. Being Poland: A New History of Polish Literature and Culture Since 1918 (Toronto: University of Toronto Press, 2018), 417-22, at 419. 
is called "Here I am" in English, "Jestem" in Polish (literally, "I am"). Among the major fictional characters are a woman, Annushka Kuzniecka, and a man, Kunicki, whose wife has disappeared while the couple is visiting a Croatian island. Historical characters include Chopin's sister, Ludwika, who is smuggling Chopin's heart into Poland, Father Benedykt Chmielowski, various scientists, especially anatomists. Then there is Josefine Soliman, who petitions Francis I, Emperor of Austria, for the body of her African father, a body which has been stuffed and kept for display, apparently as a curiosity.

The major themes of this novel include, among others, wandering, journeys, fragmentation, and time. The novel effectively makes a distinction between "wandering" without a specific destination in mind and "journeys" to or from a specific place, but these categories are permeable. The title Bieguni evokes the theme of wandering. In Polish, nouns can be grammatically masculine, feminine, or neuter. Masculine nouns are further subdivided into three categories: personal (e.g., a teacher or other human), animate (a cat), or inanimate. Similarlooking nouns can have different endings in the same declension, depending on the category to which the noun belongs. "Biegun" derives from the verb "biegać," ("to run" or "to race"). The masculine inanimate noun "biegun" means "pole" or "spindle," and can refer to both the North and the South Pole; its nominative plural form is "bieguny." The masculine personal noun "Biegun" refers to a member of a Russian heretical sect that practiced constant motion, refusing to have any fixed abode in this world dominated by the Antichrist, constantly running from place to place. ${ }^{4}$ Since this use of "Biegun" is a personal noun, the plural is "Bieguni," with an " $i$ " instead of a "y." English translations for the sect of Bieguni have included "Wanderers," "Runners," "Runaways," "Tramps," and "Deserters."

Three different translations of the title Bieguni in English, French, and German emphasize different aspects of the original title; combined, they capture the resonances of the Polish word. The French title, Les Pérégrins, cognate with the English word "peregrination," means The Wanderers. ${ }^{5}$ At times this French term can carry the suggestion of "Pilgrims." The German title is Unrast 6 ("Uneasiness"), cognate with the English "Unrest," suggesting the uneasiness behind the wanderings of the Bieguni as well as the unrest of many

4 Paul Rankov Radosavljevich, Who Are the Slavs? A Contribution to Race Psychology (Boston: The Gorham Press, 1919), Vol. 2, 81.

5 Grazyna Erhard, tr., Les Pérégrins (Paris: Les Éditions Noir sur Blanc, 2010).

6 Esther Kinsky, tr., Unrast (Frankfurt am Main: Schöffling, 2009). 
of the novel's characters. Tokarczuk has addressed this issue in an interview with the newspaper Gazeta Wyborcza [Electoral Newspaper]. She stated, as translated by Krzysztof Hoffmann in a magazine article, that the reason for using the title Flights was "the strangeness or absence of the lexeme 'bieguni' outside the Slavic languages, which for a reader from a different cultural circle would result only in the effect of exoticism. The connotations of 'flights' are much greater - it is not only 'travels by plane', but also movement in general, a shifting perspective and a bit of madness."7 The word "flights" thus evokes the actions of the Bieguni sect, who constantly take flight from place to place. In fact, much of the novel occurs on airplanes. The last chapter, integrating many of the major themes of the book, has the English word "Boarding" as its title even in the Polish text and takes place on an airplane.

Among the disadvantages of the title "Flights," however, is the inconsistency of the translation when "Bieguni" and related words appear as chapter titles or in the text. The Polish title of the thirtieth chapter contains the word "biegun," in the meaning of "pole": "Wyprawy na biegun" (Bieguni 109), literally, "Expeditions to the Pole." The title is "North Pole Expeditions" in English (Flights, 96). In the seventy-fifth chapter, which is the central episode of the novel, Annushka meets an unnamed religious wanderer (the "shrouded woman") and the following chapter is told from the latter's viewpoint. "Flights" is the English title of the first of these chapters (Flights, 226), and "What the Shrouded Runaway Was Saying" is the title of next vignette (Flights, 258). The respective Polish titles are "Bieguni" (Bieguni, 256) and "Co mowiła zakutana biegunka” (Bieguni, 291).

One nuance of "biegunka," a feminine diminutive form of "Biegun" as a member of the religious sect, is impossible to capture in translation, except by an explanatory footnote. Towards the end of the chapter titled "Flights," a red-faced policeman shouts to someone else about the religious wanderer: "It's that runaway woman" (Flights, 257). In Polish, he shouts, "to ta biegunka." He goes on to tell that woman, "We don't want any cult members around here." What is significant is that "biegunka" (but not the word "biegun" itself) has an additional meaning in Polish_- "diarrhea" (equivalent to the English slang,

7 Krzysztof Hoffmann, "Always Towards, Not From-to. Experiment, Travel, and Deconstruction in Flights by Olga Tokarczuk," Czas Kultury [Cultural Time] 113-20, March 2019. Interview of Olga Tokarczuk by Natalia Szostak, "Olga Tokarczuk: w naszym świecie granica mi dzy fikcją a faktami staje si coraz bardziej płynna," Gazeta Wyborcza, 28 April 2018. http://wyborcza.pl/7,75517,23331310,olga-tokarczuk-w-theworld-world-boundary-between-fiction-a-factami.html. 
"the runs"). Tokarczuk then demonstrates that the policeman's attitude of disrespect is characteristic of many people in authority. As the religious wanderer states:

This is why tyrants of all stripes, infernal servants, have such deep-seated hatred for the nomads - this is why they persecute the Gypsies and the Jews, and why they force all free people to settle, assigning the addresses that serve as our sentences. What they want is to create a frozen order, to falsify time's passage. . . . What they want is to pin down the world with the aid of barcodes, labelling all things, letting it be known that everything is a commodity, that this is how much it will cost you. ... Blessed is he who leaves.

Flights, 260; Bieguni, 294

Journeys are essential to this novel. Flights contains reproductions of eleven maps, including a rendition of the wanderings of Odysseus. Tokarczuk, moreover, often associates journeys with books. The title of her first novel, for example, is Podróz ludzi ksiegi [The Journey of the Book People]. ${ }^{8}$ The word for journey, podróz, also occurs in the subtitle of The Books of Jacob. She criticizes some travel guidebooks because they "have debilitated places, pinning them down and naming them, blurring their contours" (Flights, 69; Bieguni, 79). Nevertheless, Tokarczuk comments that "In my own travels I have remained faithful to two books [Chmielowski's New Athens and Melville's Moby Dick] . . because they were written with real passion, and a genuine desire to portray the world" (Flights, 70; Bieguni, 80).

Croft is excellent in a superb rendition of the excerpt that Tokarczuk includes from one of these guides. "On other strange and wonderful persons of the world" is by Reverend Benedykt Chmielowski (1700-1763), the first Polish writer of encyclopedia-like volumes; his New Athens [Nowy Atena], a 3000page work published in four volumes in 1745-46, was updated in 1754-56. Croft renders Chmielowski's article so as to convey his scholarly passion for knowledge. ${ }^{9}$ Chmielowski is a pre-Enlightenment writer, full of information

8 Podróz ludzi księgi (Warsaw: Przedświt, 1993).

9 This is in contrast to Czesław Miłosz's ridicule of Chmielowski as superstitious and superficial; Czesław Miłosz, The History of Polish Literature, 2nd ed. (Berkeley: University of California Press, 1983), 154. 
on impossible headless or dog-headed people. He cites, however, classical authors and eminent sixteenth- and seventeenth-century scientists and intellectuals for almost all his entries, from Pliny the Elder and Isidore of Seville, up through the Polish-Lithuanian prince Mikołay Radziwiłł. ${ }^{10}$ For Tokarczuk, Chmielowski partakes of the "encyclopedic passion" cited by the Swedish Academy in her Nobel Prize citation. To render such a writer in both his naïveté and his erudition, with accuracy but without being patronizing, as Croft does, is quite a difficult balance to achieve.

Fragmentation displays itself in the narrative format and in the motifs of separated individuals and of fragmented bodies-Chopin's heart is smuggled into Poland, while the rest of his body is buried in Paris; the novel includes historical accounts of human specimens collected by seventeenth-century modern anatomists and chapter devoted to an amputated leg (Flights, 207-11). The major fragmentation, however, is psychological. The narrator writes, "I suffer from ... Recurrent Detoxification Syndrome... the insistence of one's consciousness on returning to certain images, or even the compulsive search for them. . . My set of symptoms revolves around my being drawn to all things spoiled, flawed, defective, broken" (Flights, 15-17; Bieguni, 2123). Tokarczuk finds fragmentation typical of much of East European literature. Contrasting the seemingly linear history of Western Europe with the discontinuous history of Eastern Europe, with its holes, chaos, and random chance, she has concluded: "I believe the preference for the fragmentary nature associated with the narratives of Central European writers is stronger than among writers in any other place."11

A fourth leitmotif is that of time, often, but not always, with the connotation of "the right time" and associated with the concept of "the right place." Tokarczuk links "the right time" to her themes of wandering, fragmentation, exploration, and journeys. "Many people believe," she writes in a chapter titled "The Right Time and Place" ("Włascimy czas i miejsce"), "that there exists in the

10 Wojciech Paszyński, "Czarna legenda Nowych Aten Benedykta Chmielowskiego i próby jej przezwiciężenia' ["New Athens by Reverend Benedykt Chmielowski-Its Black Legend and a Possible Line of Defense"], Prace Historyczne [Historical Works] 141(1): 37-59, 2014.

11 Workshop at the 2nd World Congress of Translators of Polish Literature, June 4, 2009, Kraków. Cited in Hikaru Ogura, "On New Travel Literature and Central Europe as a Blank Space: Notes on Olga Tokarczuk's Novel Bieguni and Her Lecture Series in Japan," Slavic Eurasian Studies 30 (2016): 9-15, at 14. http://src-h.slav.hokudai.ac.jp /coe21/publish/no30_ses/. 
world's coordinate system a perfect point where time and space reach an agreement. This may even be why these people travel, leaving their homes behind, hoping that even by moving around in a chaotic fashion they will increase their likelihood of happening upon this point." (Flights, 79; Bieguni, 90). In addition, some events have to wait for the right time. "Copernicus," for instance, "was missing the rest of the solar system, planets like Uranus, which was still waiting for the right time to be discovered" (Flights, 161; Bieguni, 205).

The Greek word for this concept of time, kairos, first appears during Kunicki's search for his missing wife. He "comes upon a ticket to a museum in Trogir [in Croatia], and on the back of it a foreign word; he . . . manages to make out אaipós, which he thinks is K-A-I-R-O-S" (Flights, 46; Bieguni, 54). Later, after his wife's return, he is convinced that kairos will solve the puzzle of her disappearance: "he's even memorized that word: кaıрós. Yes, that word will explain everything to him" (Flights, 344; Bieguni, 386). Consulting three GreekPolish dictionaries, he "deciphers the word: кaıрó $\varsigma$. . . measure, moderation . . . the appropriate moment," and "in good measure, moderation." An additional entry for the related word кaıpı́ $\varsigma$ yields "done in time, purposeful . . . a dangerous place on the body where wounds are effective" (Flights, 347-48; Bieguni, 390-91). That night "he finds on Wikipedia a page about Kairos, from which he simply learns that it's a god, of little importance, forgotten, Hellenic. And that this god was discovered in Trogir" (Flights, 348; Bieguni, 391).

The concept of kairos and the god Kairos remain important, however. In the vignette titled "Kairos," an elderly professor of Greek literature visits Athens, where he recites a poem by Posidippus about an ancient sculpture. The poem, in the form of a dialogue, includes these lines:

And who are you?

Kairos the All-Mastering.

Why do you tread on tiptoes?

I ceaselessly circumnavigate the world. $\cdots$

Why did the sculptor create you?

On account of you, foreigners, and he set me at the entrance as a lesson. ${ }^{12}$

12 Epigram by Posidippus (circa 310-240 BCE) on the Statue of Kairos (Greek Anthology XVI, 275), quoted in Flights 388-89; Bieguni 434-35. Greek text, English translation, and 
The last sentence of the novel ties together themes of wandering, fragmentation, journeys, and time. The narrator is on an airplane, awaiting take-off. The lyrical translation of this line by Jennifer Croft echoes the earlier chapter title, "The Right Time and Place": "That smile of theirs [the flight attendants] holds - or so it strikes us - a kind of promise that perhaps we will be born anew now, this time in the right time and the right place" (Flights, 403; Bieguni, 434-35). ${ }^{13}$

\section{The Books of Jacob (Księgi Jakubowe)}

The Books of Jacob (2014) is an enormous chronicle of the life and times of Jacob Frank (1726-91), founder of the Frankist sect, and the cultural, literary, religious and social situation in eighteenth-century Poland. The format of the novel is innovative. In homage to Hebrew books, for example, the page numbers run backwards, with the work beginning at page 853 (page 1032 in the French version) and ending at page 1 . The subdivisions into the seven major Books and the thirty-one individual sections, however, proceed in conventional numerical order. These thirty-one sections also contain subsections that are titled but not numbered. In addition to the narrative itself, the book contains maps, illustrations, and excerpts from legal decrees, depositions, letters, and eighteenth-century literary works. Numerous characters, both historic and fictional, focalize the novel, encompassing a broad swath of society from Jewish Kabbalists, rabbinic Jewish leaders, Catholic intellectuals, Polish clergy, the higher nobility of Poland and Austria, military leaders, servants and hangers-on, early modern Polish female authors, and officials at the court of Joseph II, Emperor of Austria. Bookending the novel, and appearing at various crucial times during the narrative, are the experiences before and after death of an elderly Jewish woman, Jenta, who sees all ("Jenta widzi wszystko," Prologue: Księgi, 853, Livres de Jakób 1032). ${ }^{14}$ While much of the narrative is

an illustration of a reconstruction of the statue of Kairos in W. R. Paton, tr. and ed., The Greek Anthology, Volume V, Books 13-16 (Cambridge: Harvard University Press, Loeb Classical Library, 1918), 324-25.

13 "W ich uśmiechu ukryta jest, jak się nam zdaje, jakaś obietnica, że być może urodzimy się ponownie i tym razem będzie to włascimy czas i włascimy miejsce" (Bieguni 435). Earlier chapter title: "Włascimy czas i miejsce" (Bieguni 90).

14 To facilitate comparisons with the eventual English version, citations will be made to Book and Section numbers, as well as to the pages in the Polish and the French editions. 
realistic, the episodes involving Jenta in particular often partake of magic realism.

Mirroring Polish Baroque practice, the full title of this complex novel is:

Księgi Jakubowe albo wielka podróż przez siedem granic, pięć języków i trzy duże religie, nie licząc tych matych: opowiadana przez zmartych a przez autorkę dopetniona metoda koniektury, z wielu rozmaitych ksiag zaczerpnięta, a także wspomożona imaginacja, która to jest największym naturalnym darem czlowieka. Mądrym dla memoryalu, kompatriotom dla refleksji, laikom dla nauki, melancholikom dla rozrywki.

The Books of Jacob, or the Great Journey across Seven Frontiers, Five Languages and Three Great Religions, Not Counting Several Minor Ones: Narrated by the Dead, Their Story Being Completed by the Author According to the Method of Conjecture, Expressed in Several Books, but also Assisted by the Imagination, Which Is Humanity's Greatest Natural Gift: A Record for the Wise, A Reflection for My Compatriots, An Instruction for Laypersons, Entertainment for Melancholics. ${ }^{15}$

This title pays tribute to Nowe Ateny by Rev. Benedykt Chmielowski, whom Tokarczuk also, as I have noted, discusses in Flights/Bieguni. The title of his encyclopedia begins: Nowe Ateny; albo, Akademia wszelkiej sciencyi petna, na różne tytuly iak na classes podzielona, mądrym dla memoryatu, idiotom dla nauki, politykom dla praktyki, melancholikom dla rozrywki erygowana ... [New Athens, or the Academy Full of All Science, Divided into Subjects and Classes, A Record for the Wise, Instruction for the Uneducated, A Practicum for Politicians, a Foundation of Entertainment for Melancholics]. ${ }^{16}$ The last four phrases in the two titles are almost identical. Tokarczuk underlines the influence of Chmielowski by making him a major character in the novel and reproducing his title page in Book I, Section 4 (Księgi, 845; Livres de Jakób 963).

15 Translation mine. The full title of the soon-to-be-published English version is not available at the time of this writing.

16 Translation mine. The complete Polish text and illustrations of Nowe Ateny are available at https://literat.ug.edu.pl/ateny/index.htm (Accessed October 15, 2019). 
By alluding to Chmielowski's encyclopedia, Tokarczuk suggests that she, too, will provide an encyclopedic treatment. The rest of her subtitle indicates the areas where she will do so.

1. The Great Journey across Seven Frontiers: Jacob Frank (or Frenk), was born in 1726 as Ya'akov ben Leyb in a small village in Podolia, then part of the Polish-Lithuanian Commonwealth. When he was only a few months old he moved with his family to nearby Ottoman territories in Romania where he grew up, acquiring his nickname/ surname of "Frank," an Ottoman term for Europeans in general, often with negative connotations (e.g., a Frankish Crusader or someone suffering from a disease introduced by Europeans, such as syphilis).$^{17}$ Frank frequently travels between the Ottoman Empire and Poland, undergoes significant experiences in Lublin, Lwów, and Warsaw, is imprisoned for years in the Polish fortress at Częstochowa, then lives in Brünn (now Brno in the Czech Republic), making significant visits to Vienna in imperial AustriaHungary, and finally holding court in the German city of Offenbach, near Frankfurt. Multiple characters move back and forth across many frontiers, and one individual even emigrates to America. Two subsections are entitled "Biegun" and "Opowieść bieguna" ["The Story of the Runaway"], linking this portion of The Books to Jacob to Flights/Bieguni (Księgi, 538-34; Livres de Jakób 620-14). What seems most significant throughout the accounts of the journeys is that many of the novel's religious and social issues affect all areas of society despite national boundaries, suggesting an overall unity in eighteenth-century Eastern Europe.

2. Five Languages: Although Russian, Hebrew, and Ladino also feature in the novel, the primary languages used by the characters are Yiddish, Turkish, Polish, Latin, and German. An Ashkenazi Jew living among Ladino-speaking Sephardic Jews in Muslim lands and then in Poland, Austria and Germany, Frank spoke Yiddish as his primary language. The originals of court and ecclesiastical documents are often in Latin, while Benedykt Chmielowski (1738-1811),

17 Basic biographical information from Paweł Maciejko, The Mixed Multitude: Jacob Frank and the Frankist Movement, 1755-1816 (Philadelphia: University of Pennsylvania Press, 2011), 12-20. 
the poetess Elżbieta Drużbacha (1695-1765), and various members of the aristocracy write in Polish. German is the main language of the court of Joseph II in Vienna and in the Frankists' final place of residence, Offenbach. The connecting link for many of these languages is Antoni Moliwda-Kossakowski (1718-86), a member of the Polish aristocracy but belonging to a heretical Orthodox sect, who translates between Yiddish, Latin, Polish, and Turkish on behalf of the Frankists. Tokarczuk provides examples of overcoming the difficulties inherent in the use of multiple languages. Chmielowski wants to study the Kabbala, including the Zohar, for example, but he cannot read Hebrew or Aramaic. Elisha Schorr, an associate of Jacob Frank, gives the Polish writer the 1677 Latin translation of part of the Zohar, Kabbala Denudata [The Kabbala Unveiled]. Its author was Christian Knorr von Rosenroth, a German Protestant student of the Kabbala. The Books of Jacob reproduces the title page of Kabbala Denudata and discusses it in Book III, Section 17 (Księgi, 541-39; Livres de Jakób, 623-20). Again, the different languages are not necessarily a stumbling block to personal and cultural interactions. Tokarczuk is portraying a multi-lingual, multi-ethnic Central and Eastern Europe.

3. Three Great Religions, Not Counting Several Minor Ones: Tokarczuk depicts Frank's religious identity through numerous stages, not always mutually exclusive:

- his leadership of a Kabbalist sect following the teachings of Sabbatai Tsevi (1626-76), the self-proclaimed Jewish Messiah, who had eventually converted to Islam;

- his belief that he is the reincarnation of Sabbatai Tsevi, and then that he himself is the Messiah;

- his conversion to Islam, together with some of his followers;

- his public disputations with representatives of rabbinic Judaism, and then his conversion to Catholicism in 1759, supported by some influential members of the clergy and the aristocrats, bringing many of his followers (perhaps thousands) to baptism;

- his flirtations with becoming Russian Orthodox;

- his career as a Christian heretic, including his belief that he is a member of the Christian Trinity;

- his conviction that his daughter Ewa (Eve) was the human incarnation of the Shekhinah. For some Kabbalists, "the Shekhinah, as the last of the Sephiroth [emanations from God], becomes the 
'daughter' who, although her home is the 'form of light,' must wander into far lands." ${ }^{\prime 18}$ Ewa becomes for Jacob Frank the Fourth Person of God, now added to the Christian Trinity;

- and, finally, his leadership of a Messianic sect in Germany while outwardly professing Catholicism.

The religious issues are often a source of strife and violence. As a charismatic leader of Messianic Jews, Jacob Frank, following Sabbatai Tsevi, taught that since the Messiah has already arrived, the laws of the Torah are superseded, and the deliberate transgression of commandments, including previously prohibited sexual activities, are now positive values. These practices enraged the orthodox Jewish leaders, to the point that the rabbis and the Frankists encouraged violence against one another.

There are several episodes of prosecution and execution of Jews for the libel of ritual murder; these atrocities are historically accurate, with Tokarczuk depicting the actions and writings of some Polish bishops involved, despite papal prohibition of such trials. The number of ritual murder trials in the Polish-Lithuanian Commonwealth during the sixteenth to the eighteenth centuries has been estimated at seventy to eighty; in contrast, the witchcraft trials during the same period resulted in the execution of an estimated fifteen thousand people in Poland-Lithuania. Some of the same bishops who denounced the witchcraft trials as superstitious believed in the libel of ritual Jewish sacrifice of Christians, approving the use of torture during the trials. ${ }^{19}$ In a disputation against the orthodox Talmudists in Lwów in 1759, Frank himself, through deliberate mistranslations and esoteric number symbolism, accused the Talmud of advocating ritual murder. In 1761, near a community of Frankists in Wojsławice, Poland, a Christian child was found murdered. Tokarczuk depicts the Frankists as killing the child, and Frank's wife Chana of disguising herself as a rabbi's wife in order to inform the police that the local rabbis and other Jews were responsible for ritual murder (Book V, Section 25: Księgi, 280-76; Livres de Jakób,

18 Gershom Scholem, Major Trends in Jewish Mysticism (New York: Schocken Books, 1995), 204-42, with quotation at 230, citing Zohar I, 15b.

19 Maciejko, Mixed Multitude, 93-100. 
316-12). The accused were found guilty through confessions obtained by torture and were executed, and a massacre of the local Jewish community ensued. ${ }^{20}$

4. Narrated by the Dead, Their Story Being Completed by the Author: The novel supplements the historical accounts with plausible additions. Part of Tokarczuk's narrative concerning Jacob Frank's daughter Ewa, for example, is based on the contemporary rumor that she was the mistress of Joseph II, Emperor of Austria. Although this rumor may not have been true, later histories of the Frankist movement treat it as a fact. ${ }^{21}$ While Benedykt Chmielowski and Elżbieta Drużbacha were contemporaries, there is no historic evidence that they ever met or corresponded with each other; however, such a meeting was certainly possible.

5. Assisted by the Imagination: This is the glory of Tokarczuk's writing. By vividly picturing scenes through the eyes of different participants and enabling us to know the thoughts of multiple protagonists, she is able to present the milieux of the Frankists, the Talmudists, the Polish clergy and intellectuals, and the Polish aristocracy. The description of the village of Iwanie, for example, is particularly effective (Book III, Section 18: Księgi, 508-05 and 498-80; Livres de Jakób, 585-81 and 574-63). The author depicts Iwanie, a place where the Frankists had settled temporarily, both through the perspective of Chana Frank, Jacob's wife, and through the observations of their interpreter Moliwda. Although the English version of the entire book is still in progress, we are fortunate to have Jennifer Croft's translation of the subsection where Moliwda visits Iwanie. Here is a small excerpt:

He arrives in Iwanie on March 9, 1759, and no sooner has he arrived than he is overcome by feeling-for in Iwanie he sees the image of his own little village near Craiova, containing all the same elements, just colder and so not quite as cozy. The atmosphere is the same, a constant holiday, which the weather even seems to further: there is a slight frost, and way up in the sky the cold sun casts down bright, chilly beams. The world looks cleansed.

20 Ibid., 124-26.

21 Ibid., 211-25, 309. 
People make tracks upon the white snow, so you can follow them wherever they go.... Smoke rises in straight vertical lines from the chimneys, as though a sacrifice made in that spot were now being met with unconditional acceptance. ${ }^{22}$

Croft's rendition is elegant and vivid, yet subtle. Note the comparison of the Frankish settlement to a Polish village, the evocation of the emotional atmosphere, and the simile comparing village smoke to that of religious sacrifice.

\section{Conclusion}

As expressed in The Books of Jacob's subtitle, Imagination ... Is Humanity's Greatest Natural Gift. In The Books of Jacob Tokarczuk's imagination, exhaustive research, and writing skills have brought to life Poland in the eighteenth century, with all its ethnic groups, tragedies, atrocities, cultural achievements, aspirations, and conflicts, as well as its interconnection with Jewish, Muslim, Catholic, and Protestant developments in Eastern and Central Europe and the Ottoman Empire. Flights dissects the crucial fragmentation of modern life, developing the importance of wandering, journeys, and time. Tokarczuk's writing seamlessly shifts from mythological motifs to realist accounts of locations and objects, to subtle depictions of human activities and motives, and to the grand scope of the history of Eastern Europe and the role of religions. Her prose is passionate yet playful, promoting empathy with her characters as well as a humane acceptance of human foibles without condescension. Her comment about objects also applies to people: she is drawn to, and masterfully portrays, "all things spoiled, flawed, defective, broken" (Flights, 15-17; Bieguni, 21-23). Attention to linguistic details of the Polish language enriches her narratives. In an enactment of her motif of fragmentation, her works themselves often display a non-linear narrative with changes of style, time periods, and perspective; the insertion of vignettes and changes in focus are not intrusive, but polished narratives and essays, coalescing to a synthesis of her overall themes. Multiple episodes in Flights for example,

22 Jennifer Croft, “On Moliwda's Visit to Iwanie," October 22, 2015. https://pen.org/the -books-of-jacob/. 
emphasize kairos, whose importance becomes clear in the final chapter. The novel concludes with "the right time and the right place" ("włascimy czas i włascimy miejsce," Bieguni, 435; Flights, 403). For Tokarczuk, with the vast range of her novels and the prominence and increase in translations that will attend the recent awarding of the Nobel Prize, "the right time and the right place" is now.

Stephen Rojcewicz 